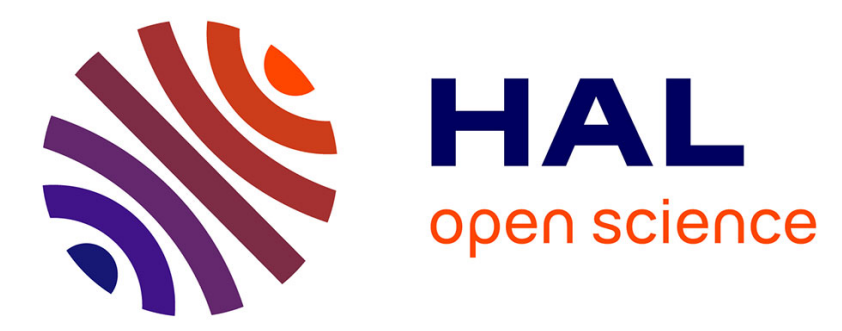

\title{
Soil aggregates: a scale to investigate the densities of metal and proton reactive sites of organic matter and clay phases in soil
}

Lorenzo Spadini, Aline Navel, Jean M.F. Martins, Erwann Vince, Isabelle Lamy

\section{To cite this version:}

Lorenzo Spadini, Aline Navel, Jean M.F. Martins, Erwann Vince, Isabelle Lamy. Soil aggregates: a scale to investigate the densities of metal and proton reactive sites of organic matter and clay phases in soil. European Journal of Soil Science, 2018, 69, 10.1111/ejss.12695 . hal-01844917

\section{HAL Id: hal-01844917 https://hal.science/hal-01844917}

Submitted on 25 Feb 2021

HAL is a multi-disciplinary open access archive for the deposit and dissemination of scientific research documents, whether they are published or not. The documents may come from teaching and research institutions in France or abroad, or from public or private research centers.
L'archive ouverte pluridisciplinaire HAL, est destinée au dépôt et à la diffusion de documents scientifiques de niveau recherche, publiés ou non, émanant des établissements d'enseignement et de recherche français ou étrangers, des laboratoires publics ou privés. 


\title{
Soil aggregates: a scale to investigate the densities of metal and proton reactive sites of organic matter and clay phases in soil
}

\author{
L. Spadinia ${ }^{\mathrm{a}}$ A.Navel ${ }^{\mathrm{a}}$, J.M.F.Martins ${ }^{\mathrm{a}}$, E.Vince ${ }^{\mathrm{a}} \&$ I. Lamy ${ }^{\mathrm{b}}$ \\ aGE UMR 5001 / UGA / CNRS / G-INP/ IRD, CS 40700, 38 058, Grenoble Cedex 9, France, \\ bINRA / AgroParisTech, UMR 1402 ECOSYS, pôle Ecotoxicologie, RD10, F-78026, Versailles Cedex, France
}

\begin{abstract}
Summary
Determining site density of reactive sites of metals in the main soil phases remains a challenging task. This study aimed to show that densities of reactive sites in soil may be assessed by a fractionation procedure based on soil being spatially organized as aggregates. The method is described with copper as a model trace element and a common silty loam soil after applying a low energy fractionation method to maintain the integrity of soil aggregates. The reactivity of five soil size fractions $(>250,250-63,63-20,20-2$ and $<2 \mu \mathrm{m})$ to protons and copper was quantified by acid-base titrations. The total proton sorption capacities were assigned to the total concentration of copper reactive sites and fitted to a linear combination of the relevant reactivity data of each phase, namely the total contents of organic carbon, copper and acid-extractable aluminium. Acid-base reactivity was linearly related to the distribution of copper, and differences between fractions were used to reconstruct the distribution of acid-base and copper-complexing sites among the clay, organic and weakly reactive residual phases. In accordance with our hypothesis that key reactive phases are mainly organic materials and clays, we used this procedure to determine the site densities of (i) two size classes of particulate organic matter, (ii) strongly reactive organic matter (e.g. soil humic and fulvic acids) and (iii) clay. The site densities and the distributions of copper obtained were used to validate our conceptual model for predicting global soil reactivity to metals.
\end{abstract}

\section{Highlights}

- Precise site densities of key soil reactive phases are often lacking in transfer modelling

- We applied specific experimental methods of aggregate analysis and partial leaching of Al phases

- Site densities of the various types of organic matter were assessed using variably amended soils

- Soil aggregate analysis is powerful for determining base parameters in element transfer modelling

\section{Introduction}

In dilute conditions, non-redox trace metals (TM) adsorbed on soil are distributed over accessible surface sites of key reactive organic and mineral phases in relation to site densities and sorption strengths. Despite the importance of such processes for environmental quality purposes, determining the distribution of metals in whole soils remains a difficult task. Research on pure organic and mineral phases has allowed the development of conceptual models of metal retention on relevant soil phases such as organic matter
(Hiemstra \& Van Riemsdijk, 1996; Tipping, 1998), clay (Tournassat et al., 2004) and X-ray amorphous iron oxides (Dzombak \& Morel, 1990; Spadini et al., 1994). However, the transfer of this knowledge from pure phases to natural soils is difficult because complex and coated phases coexist and control water fractionation (mobile and immobile), which modify the accessibility of water and reactivity of the phases (e.g. Jocteur Monrozier et al., 1993). Experimental sequential or selective extraction processes that aim to associate extracted metals with specific mineral or organic carrier phases give limited information (Zimmerman \& Weindorf, 2010). Theoretical distributions of metals originating from speciation modelling are more promising. For instance, Weng et al. (2001) modelled the distribution of sorbed copper on the organic, clay and oxide contents of 
soil types that varied in their $\mathrm{pH}$ and mineral and organic contents. Important variables need to be identified for modelling, but their experimental verification is lacking. Site density of reactive phases is one of these essential variables, but it is difficult to determine experimentally. For example, illite is classically used in modelling to represent the entire soil clay content, and its site density is fixed arbitrarily with no convincing experimental basis. For reactive iron oxides, a surface area of $600 \mathrm{~m}^{2} \mathrm{~g}^{-1}$ is proposed as a default for model input data; this value originated from titrated fresh ferrihydrite precipitates (Dzombak \& Morel, 1990). The surface area of this solid, however, evolves rapidly over time in the laboratory; therefore, the representativeness of such synthetic compounds in situ is questionable (Schwertmann \& Cornell, 2000). Finally, humic or fulvic compounds are generally used to represent reactivity of the soil's organic phase, but some organic matter is in the form of bioclasts or particulate organic matter with lower site density and different reactivities (Sebastia et al., 2008).

Research on metal reactivity in bulk soil has not, as yet, taken account of soil aggregates although they are key components in soil structure. Soil aggregates of a given size class are specific for several properties relevant to soil function, such as (i) mineral and organic composition (Tisdall \& Oades, 1982; Ducaroir \& Lamy, 1995; Balabane \& Plante, 2004), (ii) metal distribution (Besnard et al., 2001; Quenea et al., 2009; Navel \& Martins, 2014) and (iii) overall microbial functioning (Chenu et al., 2001; Constancias et al., 2013). An aggregate size class thus represents a soil domain of closely related chemical, physical and biological characteristics.

In this research, we assumed that determining reactivities of trace metals at the scale of aggregates could improve our understanding of metal distributions and more generally of biogeochemical processes in soils. We combined wet chemical methods to determine reactivity with gentle physical fractionation methods that would preserve the integrity of the soil's microstructure (Jocteur Monrozier et al., 1991; Six et al., 2004; Navel \& Martins, 2014). The overall approach adopted in this study was as follows:

1. The objective was to determine the distribution of non-redox sensitive and surface complex-forming TM such as $\mathrm{Cu}(\mathrm{II})$, $\mathrm{Zn}$ (II), $\mathrm{Pb}$ (II) and $\mathrm{Cd}(\mathrm{II})$. Copper was chosen as a test element because of its tendency to precipitate little in soil and strong association with surface-forming complexes with 'soft' acids, such as those existing on organic matter (Kirpichtchikova et al., 2006; Jacobson et al., 2007; Causse et al., 2016).

2. Organic matter (OM) and clay are the two main soil components that determine reactivity, which is widely accepted for non-tropical soils (i.e. in the absence of large amounts of reactive iron (hydr)oxide phases). Thus, the total carbon concentration (because of the filamentous nature of organic OM) and the 'partial' extraction of $\mathrm{Al}$ (because of the particulate nature of $\mathrm{Al} \mathrm{min-}$ erals) can be taken as representative measures of site densities of organic matter and Al-bearing secondary mineral phases (clays and $\mathrm{Al}$ oxides) in soil. In this study we used a silty loam vineyard soil (Mâcon, France) commonly found in France, which has been the object of a long-term experiment of controlled organic inputs (Lejon et al., 2007).

3. The total concentration of weak acids of soil solids, easily accessed from titrimetric measures, is a measure of the total concentration of metal complexation sites. In that, we followed classical reactivity determinations of pure organic and mineral phases (Dzombak \& Morel, 1990; Hiemstra \& Van Riemsdijk, 1996; Spadini et al., 2003) or organic phases (Tipping, 1998; Milne et al., 2003; Borrok et al., 2005).

4. The determination of total weak acid concentrations, total carbon and extracted $\mathrm{Al}$ in five soil size fractions (>250, 250-63, $63-20,20-2$ and $<2 \mu \mathrm{m})$, assuming constant site densities of organic carbon and extracted $\mathrm{Al}$ in all fractions, allowed their determination through linear combination analysis. The contrast in distribution of $\mathrm{Al}$ compared with $\mathrm{OM}$ phases in both coarse and fine fractions of the soil ensured a robust fit.

5. Highly reactive soil organic matter consists mainly of degraded organic matter such as humic acids and microbial compounds (e.g. extracellular polymeric substances, Causse et al., 2013). Microbes that have high site densities can also be considered as highly reactive organic matter (Borrok et al., 2005; Guiné, 2006). In contrast, particulate organic matter (POM) is comprised of clasts, which have lower site densities, and is essentially composed of non-reactive cellulose and poorly reactive lignin. In this study, in order to determine site densities of the POM size classes, we compared the same soil with or without long-term organic matter amendment. We considered that the site density of organic matter present in soil not amended with organic matter was comparable to that of highly reactive organic matter (e.g. humic acids), such as that determined in pure phase studies.

\section{Materials and methods}

\section{Soil characteristics and sampling}

A vineyard field site at Mâcon Clessé (Burgundy, France, $46^{\circ} 24^{\prime} 59^{\prime \prime} \mathrm{N}, 4^{\circ} 48^{\prime} 54^{\prime \prime} \mathrm{E}$ ) was the object of a long-term field amendment experiment. From 1991 to 2001, specific plots were amended with conifer compost (called amended soil, $100 \mathrm{~m}^{3} \mathrm{ha}^{-1}$ every 3-4 years), whereas others remained unamended (control soil). Amendment with conifer compost modifies soil physical and chemical properties compared with the control soil (Navel \& Martins, 2014). Copper fungicide (Bordeaux mixture, i.e. a hydrated mixture of $\mathrm{CuSO}_{4}$ and $\mathrm{Ca}(\mathrm{OH})_{2}$ ) was applied twice a year, which increased soil copper content in the top $5 \mathrm{~cm}$ of the soil from 15 (standard deviation, 5) to 70 (27) $\mathrm{mg} \mathrm{Cu} \mathrm{kg}^{-1}$ dry soil. The first value was determined from two soil cores sampled between $25-\mathrm{cm}$ and $60-\mathrm{cm}$ depth, whereas the second value was obtained from 112 surface soil samples (Navel, 2011). The data inside the parenthesis represent the standard deviation of the copper concentration obtained from the copper analysis of the replicated field samples. This soil has been described as a carbonate-free deep Eutric Cambisol (FAO, 1998), with a fine clay loam texture 
containing $12 \%$ sand, $57 \%$ silt and $31 \%$ clay (Navel, 2011; Bartoli \& Dousset, 2011). Exposure to long-term aqua regia led to extracted contents of 31 and $51 \mathrm{~g} \mathrm{~kg}^{-1} \mathrm{Fe}$ and 28 and $48 \mathrm{~g} \mathrm{~kg}^{-1} \mathrm{Al}$ in the control and OM-amended soils, respectively. Soil $\mathrm{pH}$ was 6.8 for the control and 6.6 for the OM-amended soils (Sebastia et al., 2007; Navel \& Martins, 2014).

No $\mathrm{Mn}$ nodules were present, which could otherwise play a role, together with organic matter and clay, in the complexation of $\mathrm{Cu}$. The soil was sampled in February 2008 (Navel \& Martins, 2014). Four replicates of each of the two soil treatments (control and OM amended) were sampled randomly from each of the four plots of each treatment and combined to obtain a representative composite sample. Each soil sample was thoroughly homogenized in a concrete mixer, air-dried and sieved to $4 \mathrm{~mm}$.

\section{Soil fractionation}

The fractionation protocol gently separates the soil aggregates in order to preserve the natural aggregation of the soil (Jocteur Monrozier et al., 1991). Thirty grams ${ }_{\mathrm{dw}}$ (dry weight) of the soils were gently dispersed in $200 \mathrm{ml}$ of distilled water in 500-ml bottles by shaking at 250 revolutions per minute (rpm) for 1 hour. Particles $>20 \mu \mathrm{m}$ that had settled were gently resuspended in $200 \mathrm{ml}$ of water. This procedure was repeated three times. The remaining particles $>20 \mu \mathrm{m}$ were then separated by wet sieving into the following three size fractions: $4 \mathrm{~mm}$ to $250 \mu \mathrm{m}$ (identified as $>250 \mu \mathrm{m}), 250-63 \mu \mathrm{m}$ and $<63 \mu \mathrm{m}$. The $63-20 \mu \mathrm{m}$ fraction was obtained by natural sedimentation for about 10 minutes (Navel \& Martins, 2014). Subsequently, the $<20 \mu \mathrm{m}$ particles in the supernatant solutions were allowed to settle by natural sedimentation for 5 to 6 hours to separate the $20-2 \mu \mathrm{m}$ and the $<2 \mu \mathrm{m}$ fractions. Finally, the $<2 \mu \mathrm{m}$ solid fraction was collected by centrifugation at $11000 \mathrm{~g}$. The quality of the fractionation procedure was evaluated by laser granulometry, performed with an automated Mastersizer 2000 (Malvern Instruments Ltd, Malvern, UK) as described by Navel \& Martins (2014). The five fractions recovered from all samples were air-dried to maintain the best possible cohesion of the aggregates. In these experiments, the dissolved concentrations of all elements of interest $(\mathrm{C}, \mathrm{H}, \mathrm{Al}$ and $\mathrm{Cu})$ were relatively small compared with the soil content, so that loss during fractionation was disregarded. The $\mathrm{pH}$ values of the soil fractions made on three replicates of each fraction of the composite soil from coarse to fine followed the order $6.5(0.2), 6.7(0.1), 6.7(0.2), 7.0(0.1)$ and 7.0 $(0.1)$ for the control and $6.8(0.1), 6.8(0.1), 7.0(0.2), 7.2(0.2)$ and $7.1(0.2)$ for the amended soil. These $\mathrm{pH}$ values were smaller than those measured for soil fractionated without air-drying (Navel, 2011).

\section{Chemical and extraction analysis}

Aluminium extraction. For both clays and Al oxides, the surface site density depends on the crystal size: the larger are the crystals, the lower is the site density. A mixture of differently sized minerals may be present. For this reason, the total $\mathrm{Al}$ in soil might not be ascribed to the Al-mineral site density. Rather, this density was related to the amount of acid-leached $\mathrm{Al}$ by aqua regia (1/3 $\mathrm{HNO}_{3} / \mathrm{HCl}$, v/v ratio), because this acid only partly dissolves clays and only marginally dissolves tectosilicates (Krause et al., 1995; Chen \& Ma, 2001; Ryan et al., 2008). The Al-containing primary phases will not dissolve readily, and other acid-sensitive Al sources can be reasonably excluded in this soil. The X-ray analysis indicated the absence of well-crystallized $\mathrm{Fe}$ and $\mathrm{Al}$ oxide phases. In the aluminium leachates, $E_{\mathrm{Al}}$ was determined in duplicate for bulk and fractionated soil samples. Briefly, $5 \mathrm{ml}$ of reagent and $0.5 \mathrm{~g}$ ground dry soil were incubated at $70^{\circ} \mathrm{C}$ for 14 hours, filtered and diluted with $50 \mathrm{ml}$ distilled water for ICP-AES (3000 DV, Perkin Elmer, Paris, France) measurements. Standard solutions were prepared in the same aqua regia matrix.

Organic matter analysis. For highly reactive (HR) organic matter, we assumed that total organic carbon content $\left(T_{\mathrm{OC}}\right)$ was proportional to complexation site density for each fraction, suggesting a unique reactivity of HR OM among fractions. This accords with recent findings demonstrating the overall high and similar site densities of various soil reactive organic compounds: humic and fulvic acids (Milne et al., 2001), bacterial exopolysaccharides and biofilms (Causse et al., 2013), bacterial cells (Borrok et al., 2005) and dissolved organic matter (Hruška et al., 2003). The site densities of these compounds have a small range between 1 and $5.7 \mathrm{mmol} \mathrm{g}_{\mathrm{dw}}^{-1}$, (Causse et al., 2013), allowing us to define a single descriptor for all these HR organic constituents. The analysis of the POM fraction of the soil studied is described in Sebastia et al. (2007). For both $\mathrm{HR}$ and POM OM, the $T_{\mathrm{OC}}$ was determined by analysing dried and crushed duplicate $20 \mathrm{mg}$ samples of bulk soil and size fractions, respectively, inserted into a FlashEA1112/FLASH 2000 Elemental Analyser equipped with a thermal conductivity detector (Thermo Scientific, Paris, France).

Determination of $\mathrm{pH}$. The $\mathrm{pH}$ values of bulk and fractionated soil samples were measured at a $1 / 10$ solid/liquid mass ratio with a calibrated combined $\mathrm{pH}$ electrode (Metrohm, Paris, France).

Copper extraction. Total copper concentrations $\left(T_{\mathrm{Cu}}\right)$ were determined in duplicate in aqua regia extracts of bulk and fractionated soil samples, following the same procedure as used for aluminium determination. Standard solutions were prepared in the same aqua regia matrix. The quantification limit for $\mathrm{Cu}$ determined in triplicate was $20 \mu \mathrm{g} \mathrm{1^{-1 }}$.

Acid-base titrimetry. This study aimed to determine the total concentrations of weakly acidic acid-base reactive sites of the soil and its fractions. The fraction-specific variable $T_{H \mathrm{~s}}$ is defined as the number of protons released into the solution from surfaces at $\mathrm{pH} 4$ and 10:

$$
T_{H \mathrm{~s}}=H_{\mathrm{S}}(\mathrm{pH}(10))-H_{\mathrm{S}}(\mathrm{pH}(4)),
$$

where $H_{\mathrm{S}}$ represents the concentration of surface protons released into the solution, referenced to an arbitrary charging state of that 
surface (Herbelin \& Westall, 1999), and $T_{H \mathrm{~s}}$ is determined by acid-base titrations at a fixed $0.1 \mathrm{M}$ ionic strength. Experimental details, the rationale for working at fixed ionic strength, the $\mathrm{pH}$ electrode calibration, the recognition of mineral dissolution and precipitation issues in titrations and issues related to cation exchange reactions are addressed in the Supporting Information.

\section{Modelling}

Modelling was based on four basic assumptions. The first assumption was that weak acids are metal complexation sites. It is assumed that at $\mathrm{pH} 4$ and 10 (the weak acid range) each surface site exchanges one proton against one copper ion. Based on that simplified assumption, the experimentally determinable $T_{H s}\left(\mathrm{~mol}_{\mathrm{Hs}} \mathrm{g}_{\mathrm{dw}}\right)$ equals the total concentration of $\mathrm{Cu}$ (II) complexing surface sites. The second basic assumption is that in all fractions, there are three sources for $T_{H \mathrm{~s}}$ : (i) soil OM ( $\left.T_{\mathrm{Hs}-\mathrm{C}}\right)$, (ii) Al-bearing secondary mineral phases (clay and $\mathrm{Al}$ oxides, $T_{\mathrm{Hs}-\mathrm{Al}}$ ) and (iii) residual non-clay, non-Al, non-OM phases $\left(T_{H \mathrm{~s}-\mathrm{Res}}\right)$.

The third assumption was that both carbon- and Al-bearing mineral phases have a unique mass-based site density in all fractions, which is, $D_{H \mathrm{~s}-\mathrm{C}}\left(\mathrm{mol}_{\mathrm{Hs}} \mathrm{g}^{-1} \mathrm{C}\right)$ for carbon and $D_{\mathrm{Hs}-\mathrm{Al}}$ for Al-bearing secondary mineral phases.

For organic carbon, a linear relation between total organic carbon $T_{\mathrm{OC}}\left[\mathrm{g}_{\mathrm{C}} \mathrm{g}_{\mathrm{dw}}^{-1}\right]$ and site density is assumed:

$$
T_{\mathrm{Hs}-\mathrm{C}}=T_{\mathrm{OC}} \times D_{H \mathrm{~s}-\mathrm{C}},
$$

based on (i) the almost exclusive presence of aged HR OM in the non-amended soil and (ii) the uniform water accessibility of this polymeric phase in all soil fractions.

In contrast to carbon in clays and oxides, site density does not relate to total $\mathrm{Al}$, but to the specific surface area. This may be approached by stripping a limited number of reactive $\mathrm{Al}$ surface layers; that is, the measured concentration of partially extracted $\mathrm{Al}$ $E_{\mathrm{Al}}$. A unique site density, $D_{\mathrm{Hs}-\mathrm{Al}}$, of the extracted $\mathrm{Al}$ is necessarily assumed in all fractions, impeded by a unique dominant $\mathrm{Al}$ phase in all fractions or by a constant mixture of $\mathrm{Al}$ minerals in all fractions. Conceptually, both statements may be considered valid in considering large aggregates as a corpus comprised of smaller aggregates.

Finally, $T_{H \mathrm{~s} \text {-calc }}$ was fitted to the experimentally determined $T_{H \mathrm{~s}}$ in all soil fractions by adjusting the fraction-independent densities $D_{H \mathrm{~s}-\mathrm{C}}$ and $D_{\mathrm{Hs} \text {-Al }}$. Differences between $T_{\mathrm{OC}}$ compared with $E_{\mathrm{Al}}$ in the fractions ensured an unambiguous result from the following calculation:

$$
\begin{aligned}
T_{H \mathrm{~s}-\mathrm{calc}} & =T_{H \mathrm{~s}-\mathrm{C}}+T_{H \mathrm{~s}-\mathrm{Al}}+T_{H \mathrm{~s}-\mathrm{Res}} \\
& =T_{\mathrm{OC}} \times D_{H \mathrm{~s}-\mathrm{C}}+E_{\mathrm{Al}} \times D_{H \mathrm{~s}-\mathrm{Al}}+T_{H \mathrm{~s}-\mathrm{Res}} .
\end{aligned}
$$

Here, $T_{H \mathrm{~s} \text {-Res }}$ is considered constant among the fractions. As shown below, its concentration is too small to affect the two fitted site densities.
In OM-amended soil, the increase in POM content affects the overall OM reactivity. The $T_{H \mathrm{~s}-\mathrm{C}}\left(\mathrm{mmol} \mathrm{g}_{\mathrm{f}}^{-1}\right)$ is consequently split into two terms, one for high-reactivity carbon (HC), $T_{\mathrm{Hs}-\mathrm{HC}}$, and one for low-reactivity carbon (LC, i.e. POM carbon), $T_{H \mathrm{~s}-\mathrm{LC}}$, as follows:

$$
\begin{aligned}
T_{\mathrm{Hs}-\mathrm{C}} & =T_{H \mathrm{~s}-\mathrm{HC}}+T_{H \mathrm{~s}-\mathrm{LC}} \\
& =T_{\mathrm{OC}-\mathrm{HC}} \times D_{H \mathrm{~s}-\mathrm{HC}}+T_{\mathrm{OC}-\mathrm{LC}} \times D_{H \mathrm{~s}-\mathrm{LC}-\mathrm{f}}
\end{aligned}
$$

The total carbon concentration is expressed as the sum of the high and low organic reactivity contributions:

$$
T_{\mathrm{OC}}=T_{\mathrm{OC}-\mathrm{HC}}+T_{\mathrm{OC}-\mathrm{LC}}
$$

and each contribution is associated with its density, $D_{H \mathrm{~s}-\mathrm{HC}}$ and $D_{H \text { s-LC-f }}$.

Concerning the HR contribution: there was almost no POM in the control soil (i.e. no low-reactivity carbon). Consequently, the site density of organic carbon determined in this soil $\left(D_{\mathrm{Hs}-\mathrm{C}}\right)$ corresponds to that of highly reactive carbon, and might equal the corresponding density in the amended soil: $D_{\mathrm{Hs}-\mathrm{HC}}=D_{\mathrm{Hs}-\mathrm{C}}$. The density $D_{H \mathrm{~s}-\mathrm{HC}}$ was consequently fixed to the value $D_{H \mathrm{~s}-\mathrm{C}}$ obtained in the control soil.

For the LR contribution: in the amended soil, POM is expected to be present as two coarse fractions of $>250 \mu \mathrm{m}$ and $250-63 \mu \mathrm{m}$. The site densities of the two fractions vary with the POM size because the specific surface of 'closed' (i.e. non-porous) solids increases with decreasing volume. Thus, in contrast to $D_{H \mathrm{~s}-\mathrm{HC}}$ the POM site density $D_{H \text { s-LC-f }}$ is fraction specific. A site density was then calculated for each of the two coarse POM fractions.

The $T_{\mathrm{Hs}-\mathrm{LC}}$ was obtained by potentiometric titration of POM isolated from soil through flotation in water, whereas $T_{\mathrm{OC}-\mathrm{LC}}\left(\mathrm{g}_{\mathrm{C}}\right.$ $\mathrm{g}^{-1}$ POM ) was obtained by total carbon analysis of POM. 'Clean' POM (i.e. POM without mineral impurities) should have a $T_{\mathrm{OC}-\mathrm{LC}}$ value close to $0.5 \mathrm{~g}_{\mathrm{C}} \mathrm{g}^{-1}{ }_{\mathrm{POM}}$, because a factor of two separates carbon and organic matter masses in soil (Pribyl, 2010). This relation enables correction for the presence of mineral impurities in floating POM. Consequently, this approach can provide the final comparison of site densities for size-specific POMs with those of HR carbon and extracted Al. Dissolved matter (copper and OM) was not considered because its contribution is negligible compared with that of the solid moieties. Scanning electron microscope figures are provided in the Supporting Information.

\section{Results}

\section{Characteristics of bulk soils and soil size fractions}

Table 1 presents the physical and chemical characteristics of the size fractions of amended (conifer compost) and control (not amended) soils. The two dominant size fractions in terms of mass are the $63-20$ and $20-2 \mu \mathrm{m}$ (Table 1 ), which is consistent with the clay loam texture of the soil.

For the control soil, $T_{\mathrm{OC}}$ concentrations (Table 1) were larger (35 and $24 \mathrm{mg} \mathrm{g}_{\mathrm{f}}^{-1}$; f fraction) in the two coarse fractions, whereas 
Table 1 Characteristics of control and amended soils

\begin{tabular}{|c|c|c|c|c|c|c|c|c|}
\hline Soil & Fractions / $\mu \mathrm{m}$ & \multicolumn{2}{|l|}{ Mass } & $\begin{array}{l}T_{\mathrm{OC}} \\
/ \mathrm{mg} \mathrm{g}^{-1}{ }_{\mathrm{f}}\end{array}$ & $\begin{array}{l}T_{\mathrm{Cu}} \\
/ \mathrm{mg} \mathrm{kg}^{-1} \mathrm{f}\end{array}$ & $\begin{array}{l}T_{H \mathrm{~s}} \\
/ \mathrm{mmol} \mathrm{g}^{-1} \mathrm{f}\end{array}$ & $\begin{array}{l}T_{H \mathrm{~s} \text {-calc }} \\
/ \mathrm{mmol} \mathrm{g}_{\mathrm{f}}^{-1}\end{array}$ & $\begin{array}{l}E_{\mathrm{Al}} \\
/ \mathrm{mgg}^{-1}{ }_{\mathrm{f}}\end{array}$ \\
\hline \multirow[t]{4}{*}{ Control soil } & $>250$ & $2.9(0.2)$ & 9.7 & $34.7(3.7)$ & $98.3(10.8)$ & $0.25(0.08)$ & 0.34 & $9.9(2.2)$ \\
\hline & $250-63$ & $3.1(1.4)$ & 10.3 & $23.6(2.7)$ & $84.8(9.6)$ & $0.28(0.01)$ & 0.29 & $16.3(1.0)$ \\
\hline & $63-20$ & $11.0(1.0)$ & 36.7 & $3.0(1.3)$ & $28.6(2.6)$ & $0.08(0.01)$ & 0.09 & $4.0(1.1)$ \\
\hline & $20-2$ & $10.0(0.8)$ & 33.3 & $19.0(4.8)$ & $90.1(11.1)$ & $0.22(0.01)$ & 0.27 & $18.9(0.6)$ \\
\hline \multirow[t]{6}{*}{ Soil amended with conifer compost } & $>250$ & $3.2(0.5)$ & 10.7 & $107.6(23.9)$ & $112.5(26.8)$ & $0.39(0.02)$ & 0.83 & $7.6(1.5)$ \\
\hline & $250-63$ & $3.9(1.1)$ & 13.0 & $51.1(11.4)$ & $121.8(16.9)$ & $0.37(0.01)$ & 0.44 & $8.8(0.8)$ \\
\hline & $63-20$ & $10.9(1.3)$ & 36.3 & $5.0(1.3)$ & $19.8(8.5)$ & $0.1(0.01)$ & 0.10 & $3.5(1.1)$ \\
\hline & $20-2$ & $9.5(0.7)$ & 31.7 & $22.8(5.2)$ & $97.1(6.1)$ & $0.27(0.01)$ & 0.29 & $17.8(1.8)$ \\
\hline & $<2$ & $2.4(0.3)$ & 8.0 & $21.0(2.9)$ & $114.7(28.0)$ & $0.39(0.02)$ & 0.39 & 40.5 (1.8) \\
\hline & Whole soil & 30.0 & & $30.3(3.6)$ & $84.0(20.8)$ & $0.21(0.01)$ & n.d. & $15.8(0.6)$ \\
\hline
\end{tabular}

$T_{\mathrm{OC}}, T_{\mathrm{Cu}}, T_{\mathrm{Hs}}, T_{\mathrm{Hs} \text {-calc }}$ and $E_{\mathrm{Al}}$ : total organic carbon, total copper, total measured and calculated proton exchange capacity and acid-extractable aluminium concentrations, respectively $\left(\mathrm{kg}_{\mathrm{f}}^{-1}, \mathrm{~g}^{-1}\right.$ : per $\mathrm{kg}$ or $\mathrm{g}$ fraction mass). Parentheses represent standard deviations from triplicate experiments.

the distribution of $E_{\mathrm{Al}}$, representing $\mathrm{Al}$ from partially extracted $\mathrm{Al}$ phases (clay and $\mathrm{Al}$ oxides), showed the reverse pattern and was largest in the two fine fractions (43.5 and $18.9 \mathrm{mg} \mathrm{g}_{\mathrm{f}}^{-1}$ ), which was expected for this clay-rich soil. Contrasting distributions of $\mathrm{Al}$ and carbon were observed in the two coarsest and two finest size fractions ( $>250$ and $250-63 \mu \mathrm{m}$ and $20-2$ and $<2 \mu \mathrm{m}$, respectively), which was consistent with the expected reactivity and distribution of clay and OM in such a clay loam soil. In contrast to $T_{\mathrm{OC}}$ and $E_{\mathrm{Al}}$ distributions, total copper concentrations, $T_{\mathrm{Cu}}$, were similar in all soil size fractions (around $100 \mu \mathrm{g} \mathrm{g}^{-1}$, Table 1), except for the $63-20-\mu \mathrm{m}$ fraction, where $T_{\mathrm{Cu}}$ was significantly less, which was similar to $T_{\mathrm{OC}}$ and $E_{\mathrm{Al}}$.

Despite variable clay and organic matter contents in the five soil size fractions, $T_{\mathrm{Cu}}$ appeared quite homogeneous in all fractions, except the poorly reactive $63-20-\mu \mathrm{m}$ fraction. This result shows that copper reacted with both clay and OM. As for $T_{\mathrm{Cu}}$, the $T_{H \mathrm{~s}}$ values of the two coarsest and two finest size fractions were similar (about $0.25 \mathrm{mmol} \mathrm{g}_{\mathrm{f}}^{-1}$ ), whereas that of the $63-20-\mu \mathrm{m}$ fraction was small $\left(0.08 \mathrm{mmol} \mathrm{g}_{\mathrm{f}}^{-1}\right)$. The similarity between $T_{\mathrm{Cu}}$ and $T_{H \mathrm{~s}}$ supports our hypothesis that copper binds preferentially to acid-base reactive sites. In the 63-20- $\mu \mathrm{m}$ fraction, $T_{\mathrm{Cu}}$ and $T_{H \mathrm{~s}}$ concentrations were small, despite being the more abundant fraction in the soil. This is consistent with the fact that the silt fraction usually comprises poorly reactive constituents, including primary minerals characterized by small specific surface areas.

For the amended soil, the patterns of distribution of $T_{H \mathrm{~s}}, T_{\mathrm{OC}}$, $T_{\mathrm{Cu}}$ and $E_{\mathrm{Al}}$ were similar to those of the control soil (Table 1), suggesting similar $\mathrm{Cu}$-binding modes in both soils. In absolute terms, $T_{H \mathrm{~s}}, T_{\mathrm{OC}}$ and $T_{\mathrm{Cu}}$ values increased in the amended soil compared with the control. The long-term organic amendment of the clay loam soil thus increased its global soil reactivity. At the scale of the size fractions, this was particularly valid for the two coarse fractions ( $>250$ and $250-63 \mu \mathrm{m}$ ) in which exogenous organic matter accumulates preferentially (Jocteur Monrozier et al., 1991; Oorts et al., 2007).
The ratios of $T_{\mathrm{Cu}} / T_{\mathrm{OC}}$ and $T_{\mathrm{HS}} / T_{\mathrm{OC}}$ are shown in Figure 1. From the coarse to the fine fractions, the ratios increased, except for the $63-20-\mu \mathrm{m}$ fraction of both the control and the amended soils. This tendency to increase with decreasing fraction size suggests that both $\mathrm{Cu}$ and protons do not react exclusively with $\mathrm{OM}$, but rather with both OM and clay. In comparison, the $T_{\mathrm{Cu}} / T_{\mathrm{Hs}}$ ratio was relatively constant between all fractions in both soils: within a standard deviation of $23 \%$ (Table 1). This relative constancy confirms that copper is bound to acid-base reactive and metal-complexing surface sites, whatever the nature of the reactive phase. This also confirms that non-protonable sites, such as cation exchange sites, are poorly involved in $\mathrm{Cu}$ retention, (Covelo et al., 2007).

In the control soil, both $T_{\mathrm{Cu}} / T_{\mathrm{OC}}$ and $T_{\mathrm{HS}} / T_{\mathrm{OC}}$ ratios of the $63-20-\mu \mathrm{m}$ fraction were relatively large compared with the other fractions. This suggests that, in addition to clay and OM, other proton and copper reactive phases exist. Overall the 63-20- $\mu \mathrm{m}$ fraction had the smallest site density for protons and copper $\left(T_{\mathrm{Hs}}, T_{\mathrm{Cu}}\right)$, with particularly small carbon and clay contents (small $T_{\mathrm{OC}}, E_{\mathrm{Al}}$ ). Thus, this fraction explicitly and sensitively revealed the presence of other $\mathrm{Cu}$ reactive sites (i.e. non-clay and non-OM phases with probably minor site densities). These sites are referred to here as 'reactive residues' $\left(T_{H \mathrm{~s}-\mathrm{Res}}\right)$.

\section{Modelling phase reactivity in the control soil}

Modelling involved varying the global $D_{H \mathrm{~s}-\mathrm{C}}, D_{H \mathrm{~s}-\mathrm{Al}}$ and $T_{\mathrm{Hs}-\mathrm{Res}}$ model parameters in order to adjust $T_{H \mathrm{~s} \text {-calc }}$ to $T_{H \mathrm{~s}}$ as closely as possible in all fractions (Equation (3), Table 1). Figure 2(a) shows that $T_{H \mathrm{~s} \text {-calc }}$ follows the trend of $T_{\mathrm{Hs}}$ among the fractions, suggesting the validity of our conceptual approach. Figure 2(a) also presents the calculated phase-specific $T_{H \mathrm{~s}-\mathrm{C}}, T_{H \mathrm{~s}-\mathrm{Al}}$ and $T_{\mathrm{Hs} \text {-Res }}$ reactivity contributions. As expected, there was a relative increase in $T_{H \mathrm{~s}-\mathrm{C}}$ in the two coarse fractions compared with the two fine fractions, whereas the opposite was observed for clay. Fitting the model to the data without considering $T_{H \mathrm{~s} \text {-Res }}$ led to an acceptable fit in all 

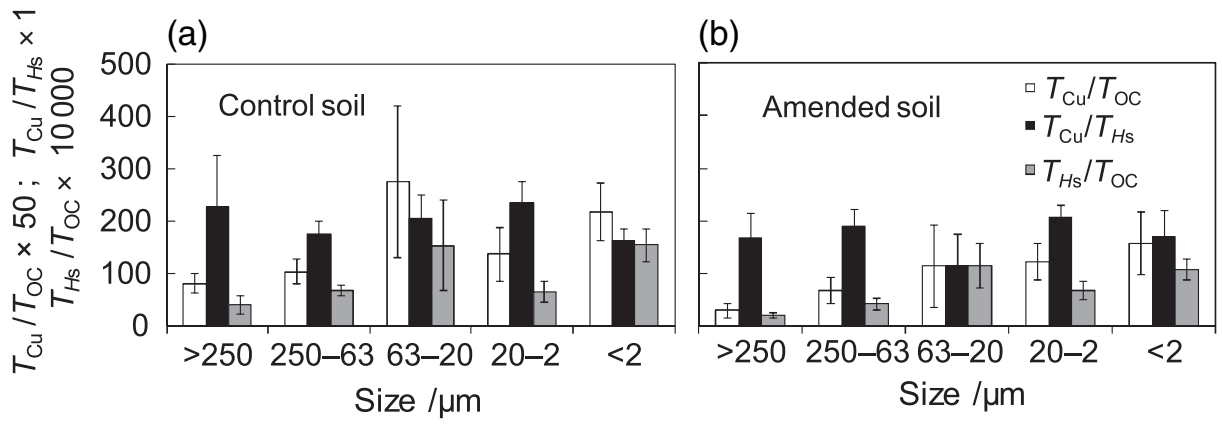

Figure 1 Total copper $\left(T_{\mathrm{Cu}}\right)$, organic carbon $\left(T_{\mathrm{OC}}\right)$, acid-base exchange capacities $\left(T_{\mathrm{Hs}}\right)$ and extractable aluminium $\left(E_{\mathrm{Al}}\right)$ ratios of the fractions of (a) the control soil and (b) the soil amended with conifer compost. Bars represent standard errors of the mean of triplicate experiments.

(a)

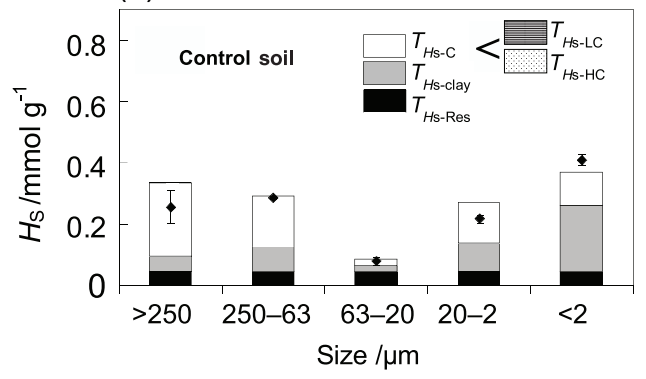

(b)

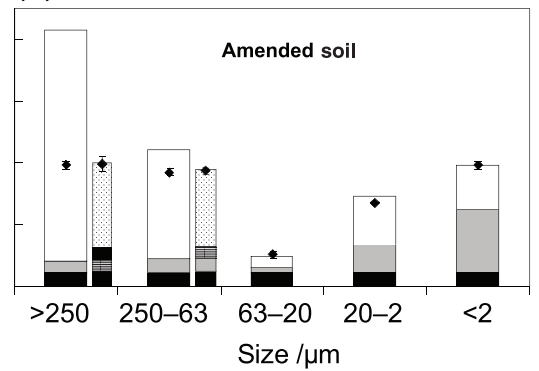

Figure 2 Experimental ( $)$ and fitted (total bar height) acid-base capacities of the fractions: (a) control and (b) amended soil. The total heights of large bars are the sum of highly reactive carbon (white, $T_{H \mathrm{~s}-\mathrm{C}}$ ), Al minerals such as clay (grey, $T_{H \mathrm{~s} \text {-clay }}$ ) and residual phase (black, $T_{H \mathrm{~s}-\mathrm{res}}$ ) contributions. Thin bars are scaled to the experimental acid-base capacities by introducing low-reactivity carbon (LC, densely dotted, with a size-class-specific site density) below the highly reactive carbon (HC, sparsely dotted).

fractions, except for the 63-20- $\mathrm{mm}$ fraction because of its low global reactivity. The $T_{H \mathrm{~s} \text {-Res }}$ value was determined in the $63-20-\mu \mathrm{m}$ fraction and considered to exist equally in all other fractions. This clearly resulted in a close agreement between $T_{H \mathrm{~s}}$ and $T_{H \mathrm{~s} \text {-calc }}$ in this fraction. We considered this $T_{H s \text {-Res }}$ contribution to be background reactivity present in all fractions. It represented about half of the reactivity of the $63-20-\mu \mathrm{m}$ fraction and constituted a minor contribution to $\mathrm{Cu}$ reactivity in the other soil size fractions.

Figure 2(a) shows that $T_{\mathrm{Hs} \text {-calc }}>T_{\mathrm{Hs}}$ in the $>250-\mu \mathrm{m}$ fraction. This is the expected tendency for POM present in the coarse fractions. The low site density of this type of OM compared with that of HR organic matter led to $T_{\mathrm{H} \text { s-calc }}$ being overestimated. The analysis of the amended soil, which contained far more POM, consequently required different types of $\mathrm{OM}$ to be considered.

\section{Modelling of the phase reactivity of the amended soil}

Organic amendment induced the doubling of $T_{\mathrm{OC}}$ from $15.3 \mathrm{~g}_{\mathrm{C}} \mathrm{kg}_{\mathrm{dw}}^{-1}$ (control soil) to $30.3 \mathrm{~g}_{\mathrm{C}} \mathrm{kg}^{-1}{ }_{\mathrm{dw}}$ (amended soil, Table 1) at the sampling date (February 2008). The $T_{\text {OC-amended }} / T_{\text {OC-control }}$ ratio was $3.1,2.1,1.7,1.2$ and 1.4 in the five fractions (from the coarsest to the finest, respectively), confirming that exogenous $\mathrm{OM}$ accumulates preferentially in coarse soil fractions before being progressively incorporated into the microaggregates (Navel \& Martins, 2014). The $T_{H \mathrm{~s} \text {-amended }} / T_{\mathrm{Hs} \text {-control }}$ ratio decreased correspondingly in these five fractions (1.6, 1.3, 1.3, 1.2 and 1.0), although the decrease was smaller than for the $T_{\mathrm{OC} \text {-amended }} / T_{\mathrm{OC} \text {-control }}$ ratio. In the $>250$ - $\mu \mathrm{m}$ fraction, a three-fold increase of $T_{O C}$ (34.7 to $107.6 \mathrm{mg} \mathrm{g}^{-1}$, non-amended to amended soil) induced only $60 \%$ of the increase in reactivity of $H_{\mathrm{S}}$. This is consistent with the incorporation into the soil of poorly reactive OM (i.e. POM) during the period of amendment. The application of Equation (3) to the amended soil, using as a first approximation the densities, $D_{\mathrm{Hs}-\mathrm{C}}$ and $D_{H \mathrm{~s}-\mathrm{Al}}$, fitted to the control soil, resulted in large $T_{H \text { s-calc-amended }}$ values (Figure 2(b)) for the amended soil compared with its experimental value $T_{H \mathrm{~s}}$. This presupposes the exclusive presence of highly reactive OM in all fractions, which clearly did not apply to the amended soil. The excess reactivity calculated was larger in the $>250-\mu \mathrm{m}$ fraction than in the $250-63-\mu \mathrm{m}$ fraction, indicating greater reactivity of the POM present in the latter. This is consistent with the progressive degradation of POM, leading to the presence of smaller OM particles. This fits the expected size-reactivity relation of POM and confirms former findings of POM reactivities measured in this soil (Sebastia et al., 2008).

\section{Discussion}

\section{Site densities of soil Al mineral phases}

In the control soil, the calculated $D_{H \mathrm{~s}-\mathrm{Al}}$, representing clay and Al oxides, was 0.005 or $0.135 \mathrm{~mol} \mathrm{~mol}^{-1} \mathrm{Al}$. Thus, one of the 
7.4 extracted $\mathrm{Al}$ atoms can be considered acid-base reactive. This means that the acid dissolved more than one surface layer. Schematically, one may consider that an average of seven consecutive surface layers was stripped from reactive $\mathrm{Al}$ minerals. However, $E_{\mathrm{Al}}$ represented about $1.7 \%$ only of the soil mass (Table 1), which is a small fraction of the total $\mathrm{Al}$ contained in the clay of this soil (31\% clay, Bartoli \& Dousset, 2011). Thus, only a minor fraction of clay and or Al oxides, or both, was dissolved, as expected. Under these conditions, the extracted $\mathrm{Al}$ can be considered to represent a measure of the density of clay edges and $\mathrm{Al}$ oxide sites. The aqua regia reactant might be too strong, however, a diluted form could be used in further studies.

\section{Site densities of organic matter phases in soil}

In the control soil, the site density, $D_{H \mathrm{~s}-\mathrm{C}}$, of the measured organic carbon was $6.94 \mathrm{mmol} \mathrm{g}_{\mathrm{C}}{ }^{-1}$ or $83.3 \mathrm{mmol} \mathrm{mol}_{\mathrm{C}}{ }^{-1}$. Values of 7.74 and $5.70 \mathrm{mmolg}_{\mathrm{OM}}{ }^{-1}$ calculated from pure-phase studies are commonly accepted for fulvic and humic acids, respectively (Milne et al., 2001), which can be converted to 15.48 and $11.4 \mathrm{mmol} \mathrm{g}_{\mathrm{C}}{ }^{-1}$ using a conversion factor of $0.5 \mathrm{~g}_{\mathrm{C}} \mathrm{g}_{\mathrm{OM}}{ }^{-1}$ (Pribyl, 2010; Causse et al., 2013). The $D_{H \mathrm{~s}-\mathrm{C}}$ is thus about half of the site densities observed for fulvic and humic acids, which are among the most reactive OM types in soil. These results show that the HR OM assessed at the scale of aggregates compares with purified HR OM in terms of site density and that aqueous solutes can easily access these sites in the soil studied.

In the same amended soil, Sebastia et al. (2008) found $T_{\mathrm{OC}-\mathrm{LC}}$ values of 0.38 (0.01) $\mathrm{g} \mathrm{C} \mathrm{g}_{\text {POM }}^{-1}$ and 0.28 (0.03) $\mathrm{g} \mathrm{C} \mathrm{g}_{\text {POM }}^{-1}$ for the 2000-200- $\mu \mathrm{m}$ and 200-50- $\mu \mathrm{m}$ POM size-fractions, respectively. These fractions can be compared with the $>250-\mu \mathrm{m}$ and $250-63-\mu \mathrm{m}$ soil size fractions of the present study. The decrease in $T_{\mathrm{OC}-\mathrm{LC}}$ with particle size relates to increasing mineral impurities in POM. 'Clean' POM should have a carbon/particle mass ratio of $0.53 \mathrm{~g} \mathrm{C} \mathrm{g}^{-1}$ OM , regardless of the size because this ratio characterizes both wood and humic substances, the principal constituents of POM (Volkoff et al., 1988; Causse et al., 2013). Consequently, about half of the POM mass in the soil of this study relates to mineral impurities. The $T_{\mathrm{Hs}-\mathrm{LC}}$, the acid-base exchange capacities of the two POM fractions, were retrieved from the same study of the same soil (Sebastia et al., 2008): 0.219 and $0.627 \mathrm{mmol} \mathrm{g}^{-1}$ POM, respectively. The POM site densities, $D_{H \text { s-LC-f }}=T_{H \text { s-LC }} / T_{\mathrm{OC}-\mathrm{LC}}$, were 0.57 and $2.25 \mathrm{mmol} \mathrm{g}^{-1}$ C for the coarse and fine POM fractions, respectively. These values are 12 and 3.1 times less, respectively, than $D_{H \mathrm{~s}-\mathrm{HC}}$, the site density of HR carbon $\left(6.94 \mathrm{mmol} \mathrm{g}^{-1} \mathrm{C}\right)$. It follows that one organic carbon out of 12 (for HC), out of 40 (for low-reactive carbon LC in the $250-63 \mu \mathrm{m}$ fraction) and out of 132 (for LC in the $>250 \mu \mathrm{m}$ fraction) has an acid-base reactive surface group.

More generally, the results of our study accord with previous findings (Besnard et al., 2001; Six et al., 2004; Oorts et al., 2007; Sebastia et al., 2007), which showed that the size distribution of POM evolves with time, but not the reactivity of a given size fraction. Conceptually, the POM fragments of particles become smaller and thus more reactive as they are degraded by soil organisms, but they remain less reactive than HR OM. Previous $\mu$-SXRF studies have shown that soil POM can concentrate copper locally (Jacobson et al., 2007), suggesting POM is an entity of 'greatest reactivity' in soil, which was not the case in the present study. Such spectroscopic methods reveal only the volumetric density of sorbed metals (in this case copper). When interpreting such measurements, one must keep in mind that locally concentrated copper sorbed on POM particles levels off from the high-reactivity $\mathrm{OM}$, which is 'diluted' in the relatively weak reactive clay phase. Metals associated with highly reactive OM are then likely to be less visible by spectroscopic methods. Extractive and spectroscopic methods thus appear to be compatible and complementary because they each provide a specific focus on different definitions of site density.

The method presented in this study also enables the distribution of OM and site densities of LR and HR OM to be assessed. The $T_{\mathrm{OC}-\mathrm{HC}}$ was obtained by scaling $T_{H \mathrm{~s} \text {-calc }}$ to $T_{\mathrm{Hs}}$, keeping the other reactivity contributions unchanged. The high-reactivity carbon (i.e. $T_{\mathrm{Hs}-\mathrm{HC}}$ ) represented 87.2 and $87.4 \%$ of the organic carbon-based proton reactivity $T_{H \mathrm{~s}-\mathrm{C}}$ in the $>250-\mu \mathrm{m}$ and $250-63-\mu \mathrm{m}$ fractions, respectively (Figure $2 \mathrm{~b}$, thin columns). These values represent 36 and $69 \%$ of the total carbon mass in these fractions. The remaining mass of organic carbon relates to low-reactivity OM (POM). In the $>250-\mu \mathrm{m}$ soil fraction, the high-reactivity $\mathrm{OM}$ is dominant in reactivity compared with POM, but not in mass. Because of uncertainties in the measurements, we considered this statement to be qualitatively justifiable only.

\section{Extraction of other mineral phases}

In this study a robust result was obtained when restricting the analysis to OM and clay in order to take into account their different distributions among the coarse and fine soil fractions, and also because we limited the number of phases determined to two in the control soil and three in the amended soil. This approach could be extended to other soil phases. For example, Fe could be partially extracted as with $\mathrm{Al}$ and the data interpreted similarly by relating linearly the proportion of partially extracted $\mathrm{Fe}$ to water-accessible surface sites of Fe minerals. Carbonated phases are sensitive to strong acids and would require a specific treatment. With acid-base titrations the presence of acid-sensitive phases such as carbonate can be assessed easily by a steep increase in the slope of $H_{\mathrm{S}}$ plotted against $\mathrm{pH}$ at the known $\mathrm{pH}$ of dissolution ( $\mathrm{pH} \sim 5.5$ ). In such cases the protocol would have to be adapted as described in the Supporting Information section.

\section{Application of the calculation approach to a series of soil types}

The calculation approach we described may be applied to a series of bulk soils as shown by Weng et al. (2001), rather than to fractions of a single soil. That means comparing the $\mathrm{C}$ and $\mathrm{Al}$ contents between the different soils instead of between the fractions of a single soil. However, one would have to take into account the two 
main assumptions: an implicit assumption that unique $\mathrm{Al}$ and $\mathrm{C}$ site densities prevail in the different soils and an explicit assumption concerning uniform leaching behaviour of Al mineral phases among the different soils. Such strong assumptions apply more to fractions of a unique soil than to different soils.

\section{Conclusion and perspectives}

In this study, the acid-extractable $\mathrm{Al}$, the $\mathrm{OM}$ content and the acid-base exchange capacity in the fractions of a silty clay soil were combined linearly. This approach succeeded in determining site densities of clayey and organic phases in the soil studied. By comparing soil plots variably amended with organic matter, the method enabled the site densities of highly reactive organic matter compared with low-reactive organic matter of two POM size classes to be quantified.

Our results were consistent with those reported in the literature in terms of site densities of highly reactive OM. This suggests that an approach based on the analysis of soil size fractions enables the determination of metal-reactive site densities of the main reactive phases in soil in which OM and clay are assumed as the dominant reactive phases, which is the case in most soils. Therefore, we propose to validate future multisite modelling studies with such approaches, which enable site densities to be determined instead of being arbitrarily fixed. The calculation approach is also potentially applicable to a series of bulk soils instead of a series of soil size fractions provided that some basic working hypotheses are validated first. The method may also be expanded to include additional phases such as iron oxides when working with iron-rich soil. In our study the number of phases determined was limited to the dominant reactive phases of the silty loam soil (HR and LR OM and clay). This enabled site densities of the dominantly reactive phases of this soil to be determined unambiguously.

\section{Supporting Information}

The following supporting information is available in the online version of this article:

Figure S1. Acid-base titration curves of the five soil size fractions for (a) the control and (b) compost-amended Clessé soil. Bars represent standard errors of the mean of triplicate experiments.

Figure S2. Sample SEM images of (a) an aggregate and (b) a bioclast of the $>250 \mu \mathrm{m}$ fraction.

\section{Acknowledgements}

We acknowledge the French National Centre for Scientific Research (CNRS INSU) for its financial support through the EC2CO-Cytrix funding (Project MOBIPO-Cu). We thank Philippe Crozier from the Chambre d'Agriculture de Saône-et-Loire and Daniel Lacroze, the owner of the study site, for providing field site access and permitting soil sampling. The IGE is part of Labex OSUG@2020 (ANR10 LABX56).

\section{References}

Balabane, M. \& Plante, A.F. 2004. Aggregation and carbon storage in silty soil using physical fractionation techniques. European Journal of Soil Science, 55, 415-427.

Bartoli, F. \& Dousset, S. 2011. Impact of organic inputs on wettability characteristics and structural stability in silty vineyard topsoil. European Journal of Soil Science, 62, 183-194.

Besnard, E., Chenu, C. \& Robert, M. 2001. Influence of organic amendments on copper distribution among particle-size and density fractions in Champagne vineyard soils. Environmental Pollution, 112, 329-337.

Borrok, D., Turner, B.F. \& Fein, J.B. 2005. A universal surface complexation framework for modeling proton binding onto bacterial surfaces in geologic settings. American Journal of Science, 305, 826-853.

Causse, B., Spadini, L., Martins, J.M.F., Lenoir, T., Heyraud, A. \& Delolme, C. 2013. Xanthan exopolysaccharide: acid-base reactivity related to structure and conformation. A model for understanding the reactivity of degraded and colloidal soil organic matter. Chemical Geology, 359, $150-158$.

Causse, B., Spadini, L., Sarret, G., Faure, A., Travelet, C., Madern, D. et al. 2016. Xanthan exopolysaccharide: $\mathrm{Cu}^{2+}$ complexes affected from the $\mathrm{pH}$-dependent conformational state; implications for environmentally relevant biopolymers. Environmental Science \& Technology, 50, 3477-3485.

Chen, M. \& Ma, L.Q. 2001. Comparison of three aqua regia digestion methods for twenty Florida soils. Soil Science Society of America Journal, 65, 491.

Chenu, C., Hassink, J. \& Bloem, J. 2001. Short-term changes in the spatial distribution of microorganisms in soil aggregates as affected by glucose addition. Biology and Fertility of Soils, 34, 349-356.

Constancias, F., Prévost-Bouré, N., Terrat, S., Aussems, S., Nowak, V., Guillemin, J.-P. et al. 2013. Microscale evidence for a high decrease of soil bacterial density and diversity by cropping. Agronomy for Sustainable Development, 34, 831-840.

Covelo, E.F., Vega, F.A. \& Andrade, M.L. 2007. Simultaneous sorption and desorption of $\mathrm{Cd}, \mathrm{Cr}, \mathrm{Cu}, \mathrm{Ni}, \mathrm{Pb}$, and $\mathrm{Zn}$ in acid soils: II. Soil ranking and influence of soil characteristics. Journal of Hazardous Materials, 147, $862-870$.

Ducaroir, J. \& Lamy, I. 1995. Evidence of trace metal association with soil organic matter using particle size fractionation after physical dispersion treatment. The Analyst, 120, 741.

Dzombak, D.A. \& Morel, F.M.M. 1990. Surface Complexation Modeling: Hydrous Ferric Oxide. Wiley, New York.

FAO 1998. World Reference Base for Soil Resources. World Soil Resources Report 84, FAO, Rome.

Guiné, V. 2006. Approche expérimentale et théorique de la réactivité de surface et de la mobilité des collö̈des bactériens en milieu poreux: impact sur le transfert accéléré de métaux lourds et intérêt pour la bio-dépollution des sols. $\mathrm{PhD}$ thesis of the Université Joseph Fourier Grenoble.

Herbelin, A.L. \& Westall, J.C. 1999. FITEQL 4.0: A Computer Program for Determination of Chemical Equilibrium Constants from Experimental Data. Department of Chemistry, Oregon State University, Corvallis, OR. Hiemstra, T. \& Van Riemsdijk, W.H. 1996. A surface structural approach to ion adsorption: the charge distribution (CD) model. Journal of Colloid and Interface Science, 179, 488-508. 
Hruška, J., Köhler, S., Laudon, H. \& Bishop, K. 2003. Is a universal model of organic acidity possible: comparison of the acid/base properties of dissolved organic carbon in the boreal and temperate zones. Environmental Science \& Technology, 37, 1726-1730.

Jacobson, A.R., Dousset, S., Andreux, F. \& Baveye, P.C. 2007. Electron microprobe and synchrotron X-ray fluorescence mapping of the heterogeneous distribution of copper in high-copper vineyard soils. Environmental Science \& Technology, 41, 6343-6349.

Jocteur Monrozier, L., Ladd, J.N., Fitzpatrick, R.W., Foster, R.C. \& Rapauch, M. 1991. Components and microbial biomass content of size fractions in soils of contrasting aggregation. Geoderma, 50, 37-62.

Kirpichtchikova, T.A., Manceau, A., Spadini, L., Panfili, F., Marcus, M.A. \& Jacquet, T. 2006. Speciation and solubility of heavy metals in contaminated soil using X-ray microfluorescence, EXAFS spectroscopy, chemical extraction, and thermodynamic modeling. Geochimica et Cosmochimica Acta, 70, 2163-2190.

Krause, P., Erbslöh, B., Niedergesäß, R., Pepelnik, R. \& Prange, A. 1995. Comparative study of different digestion procedures using supplementary analytical methods for multielement-screening of more than 50 elements in sediments of the river Elbe. Fresenius' Journal of Analytical Chemistry, 353, 3-11

Lejon, D.P.H., Sebastia, J., Lamy, I., Chaussod, R. \& Ranjard, L. 2007. Relationships between soil organic status and microbial community density and genetic structure in two agricultural soils submitted to various types of organic management. Microbial Ecology, 53, 650-663.

Milne, C.J., Kinniburgh, D.G. \& Tipping, E. 2001. Generic NICA-Donnan model parameters for proton binding by humic substances. Environmental Science \& Technology, 35, 2049-2059.

Milne, C.J., Kinniburgh, D.G., van Riemsdijk, W.H. \& Tipping, E. 2003. Generic NICA-Donnan model parameters for metal-ion binding by humic substances. Environmental Science \& Technology, 37, 958-971.

Monrozier, L., Guez, P., Chalamet, A., Bardin, R., Martins, J. \& Gaudet, J.P. 1993. Distribution of microorganisms and fate of xenobiotic molecules in unsaturated soil environments. Science of The Total Environment, 136, $121-133$.

Navel, A. 2011. Distribution, spéciation, impact et transfert du cuivre dans un sol sous vigne: rôle de la structuration spatiale et du statut organique. $\mathrm{PhD}$ thesis of the Université Grenoble Alpes [WWW document]. URL http://tel.archives-ouvertes.fr/docs/00/68/00/30/PDF/23181_NAVEL_ 2011_archivage.pdf [accessed on 11 July 2016].

Navel, A. \& Martins, J.M.F. 2014. Effect of long term organic amendments and vegetation of vineyard soils on the microscale distribution and biogeochemistry of copper. Science of the Total Environment, 466-467, 681-689.

Oorts, K., Bossuyt, H., Labreuche, J., Merckx, R. \& Nicolardot, B. 2007. Carbon and nitrogen stocks in relation to organic matter fractions, aggregation and pore size distribution in no-tillage and conventional tillage in northern France. European Journal of Soil Science, 58, 248-259.

Pribyl, D.W. 2010. A critical review of the conventional SOC to SOM conversion factor. Geoderma, 156, 75-83.
Quenea, K., Lamy, I., Winterton, P., Bermond, A. \& Dumat, C. 2009. Interactions between metals and soil organic matter in various particle size fractions of soil contaminated with waste water. Geoderma, $\mathbf{1 4 9}$, 217-223.

Ryan, P., Hillier, S. \& Wall, A. 2008. Stepwise effects of the BCR sequential chemical extraction procedure on dissolution and metal release from common ferromagnesian clay minerals: a combined solution chemistry and X-ray powder diffraction study. Science of the Total Environment, 407, 603-614.

Schwertmann, U. \& Cornell, R.M. (eds) 2000. Iron Oxides in the Laboratory. Wiley-VCH Verlag GmbH, Weinheim [WWW document]. URL http://doi.wiley.com/10.1002/9783527613229 [accessed on 16 October 2015].

Sebastia, J., Labanowski, J. \& Lamy, I. 2007. Changes in soil organic matter chemical properties after organic amendments. Chemosphere, $\mathbf{6 8}$, 1245-1253.

Sebastia, J., van Oort, F. \& Lamy, I. 2008. Buffer capacity and Cu affinity of soil particulate organic matter (POM) size fractions. European Journal of Soil Science, 59, 304-314.

Six, J., Bossuyt, H., Degryze, S. \& Denef, K. 2004. A history of research on the link between (micro)aggregates, soil biota, and soil organic matter dynamics. Advances in Soil Structure Research, 79, 7-31.

Spadini, L., Manceau, A., Schindler, P.W. \& Charlet, L. 1994. Structure and stability of $\mathrm{Cd}^{2+}$ surface complexes on ferric oxides: 1. Results from EXAFS spectroscopy. Journal of Colloid and Interface Science, $\mathbf{1 6 8}$, $73-86$.

Spadini, L., Schindler, P.W., Charlet, L., Manceau, A. \& Vala Ragnarsdottir, K. 2003. Hydrous ferric oxide: evaluation of Cd-HFO surface complexation models combining $\mathrm{Cd}_{\mathrm{K}}$ EXAFS data, potentiometric titration results, and surface site structures identified from mineralogical knowledge. Journal of Colloid and Interface Science, 266, 1-18.

Tipping, E. 1998. Humic ion-binding model VI: an improved description of the interactions of protons and metal ions with humic substances. Aquatic Geochemistry, 4, 3-48.

Tisdall, J.M. \& Oades, J.M. 1982. Organic matter and water-stable aggregates in soils. Journal of Soil Science, 33, 141-163.

Tournassat, C., Ferrage, E., Poinsignon, C. \& Charlet, L. 2004. The titration of clay minerals II. Structure-based model and implications for clay reactivity. Journal of Colloid and Interface Science, 273, 234-246.

Volkoff, B., Polo, A. \& Cerri, C. 1988. Caractéristiques biochimiques des acides humiques des sols tropicaux du Brésil. Distinction fondamentale entre les sols équatoriaux et les sols des régions à climat tropical contrasté. Comptes Rendus de l'Académie des Sciences Série, 307(Serie 2), 95-100.

Weng, L., Temminghoff, E.J.M. \& Van Riemsdijk, W.H. 2001. Contribution of individual sorbents to the control of heavy metal activity in sandy soil. Environmental Science \& Technology, 35, 4436-4443.

Zimmerman, A.J. \& Weindorf, D.C. 2010. Heavy metal and trace metal analysis in soil by sequential extraction: a review of procedures. International Journal of Analytical Chemistry, 2010, 1-7. 